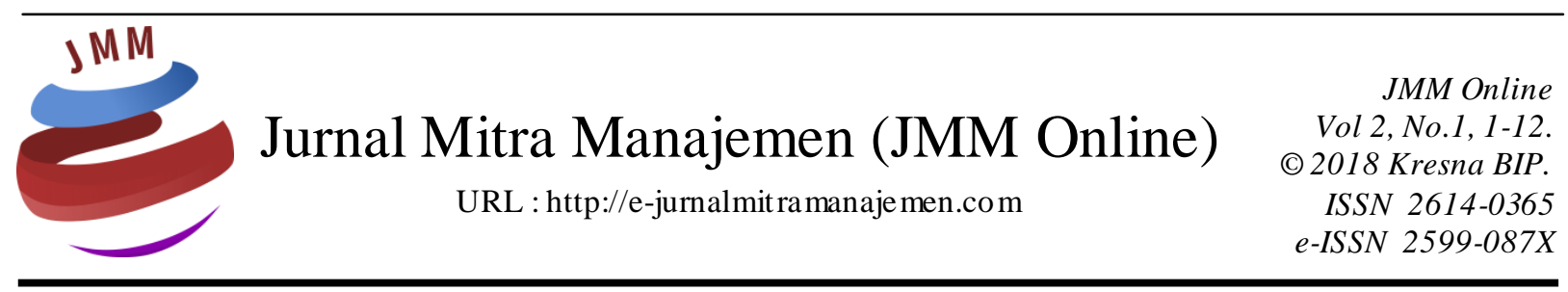

\title{
PENGARUH FAKTOR-FAKTOR EKONOMI MAKRO : INFLASI, KURS, HARGA MINYAK, DAN HARGA BAHAN BANGUNAN TERHADAP HARGA SAHAM PER USAHAAN PROPERTI DI BEI
}

\author{
Posma Sariguna Johnson Kennedy ${ }^{1}$, Rupiko Hay rani ${ }^{2}$ \\ Fakultas Ekonomi dan Bisnis \\ Universitas Kristen Indonesia, Jakarta
}

INFORMASI ARTIKEL

Dikirim : 09 Januari 2018

Revisi pertama :13 Januari 2018

Diterima : 13 Januari 2018

Tersedia online : 23 Januari 2018

Kata Kunci : Inflasi, Harga Saham, Nilai Tukar, Harga Minyak, Indeks Harga Bahan Bangunan

Email :posmahutasoit@gmail ${ }^{1}$ rupikohayrani21@gmail.com ${ }^{2}$

\section{ABSTRAK}

Tujuan dari penelitian ini adalah untuk melihat bagaimana pengaruh dari variabel-variabel ekonomi makro, yaitu inflasi, nilai tukar, harga minyak dan indeks harga bahan bangunan terhadap perubahan harga saham untuk perusahaan-perusahaan sektor properti di Bursa Efek Indonesia (BEI) secara parsial atau simultan untuk periode 2008-2015. Pengambilan sampel dalam penelitian ini dilakukan dengan menggunakan purposive sampling, dengan jumlah sampel dalam penelitian ini adalah lima perusahaan sektor properti di BEI. Teknik analisis data yang digunakan adalah statistik deskriptif, uji asumsi klasik dan pengujian hipotesis. Hasil penelitian menunjukkan bahwa inflasi, nilai tukar dan harga minyak berpengaruh terhadap perubahan harga saham. Namun indeks harga bahan bangunan tidak berpengaruh terhadap perubahan harga saham. Hasil pengujian $F$ menjelaskan bahwa inflasi, nilai tukar, harga minyak, dan indeks harga bahan bangunan berpengaruh terhadap perubahan harga saham sektor properti perusahaan secara simultan. 


\section{PENDAHULUAN \\ Latar Belakang}

Kebangkrutan yang terjadi pada beberapa perusahaan besar di Amerika Serikat yang dikarenakan oleh krisis keuangan dunia yang terjadi pada tahun 2008. Hal tersebut terjadi karena krisis kredit perumahan dan produk sekuritas. Salah satu dampak dari krisis finansial global adalah perlambatan pertumbuhan ekonomi. Krisis ekonomi di Indonesia juga menunjukkan hubungan antara kondisi makro ekonomi terhadap kinerja saham, dimana dengan melemahnya nilai tukar rupiah telah berdampak besar terhadap pasar modal di Indonesia. Dengan terjadinya krisis membuat para investor untuk berpikir dua kali dalam berinvestasi di pasar modal. Secara umum, pasar modal merupakan tempat kegiatan perusahaan mencari dana untuk membiayai kegiatan usahanya. Pasar modal merupakan salah satu sumber dana bagi pembiayaan pembangunan nasional pada umumnya dan emiten pada khususnya di luar sumber-sumber yang umum dikenal, seperti tabungan pemerintah, tabungan masyarakat, kredit perbankan dan bantuan luar negeri.

Pasar modal yang ada di Indonesia merupakan pasar yang sedang berkembang yang sangat rentan terhadap kondisi ekonomi mikro perusahaan maupun keadaan ekonomi makro negara. Pengaruh mikro tidak mempengaruhi kinerja perusahaan secara seketika, melainkan secara perlahan dan dalam jangka waktu yang panjang. Sebaliknya, harga saham akan terpengaruh dengan seketika oleh perubahan faktor makro ekonomi karena para investor lebih cepat bereaksi. Ketika perubahan ekonomi makro itu terjadi, para investor akan memperhitungkan dampaknya baik yang positif maupun yang negatif terhadap kinerja perusahaan beberapa bulan atau tahun ke depan, kemudian mengambil keputusan membeli, menjual atau menahan saham yang bersangkutan (Samsul, 2016).

Salah satu faktor yang mempengaruhi pergerakan harga saham adalah inflasi. Tingkat inflasi merupakan faktor yang harus dipertimbangkan dalam proses investasi. Inflasi merupakan indikator ekonomi yang menyebabkan kenaikan harga barang dan dalam suatu periode. Adanya inflasi yang tinggi akan menyebabkan naiknya biaya produksi. Investor akan tertarik untuk menginvestasikan dananya ketika inflasi stabil, sehingga volume perdagangan di pasar modal akan meningkat dan akan diikuti o leh penguatan indeks harga saham yang menjadi tolak ukur kinerja pasar modal.

Faktor ekonomi makro lainnya adalah nilai tukar atau kurs, merupakan sejumlah mata uang lokal yang dibutuhkan untuk membeli satu mata uang asing (Tandellin, 2010). Apabila kurs rupiah menguat, mengindikasikan perekonomian sedang baik, sehingga para investor mau berinvestasi pada saham. Sebaliknya, apabila rupiah melemah maka perekonomian dalam keadaan kurang baik, sehingga investor akan sangat berhati-hati dalam menginvestasikan dananya, karena hal tersebut erat kaitannya dengan keuntungan yang akan didapat. Permintaan saham berkurang yang berkurang akan menyebabkan penurunan pada harga saham.

Harga minyak adalah salah satu yang dapat mempengaruhi pergerakan saham juga. Hal tersebut dikarenakan kenaikan harga minyak mentah akan mendorong investor untuk berinvestasi. Karena menganggap kenaikan harga minyak menunjukkan meningkatnya permintaan global, yang berarti membaiknya ekonomi global, sehingga akan meningkatkan laba dan kinerja perusahaan. Adanya peningkatan permintaan 
saham akan meningkatkan perdagangan saham yang berdampak pada meningkatnya harga saham perusahaan. Perusahaan properti merupakan unit bisnis yang bergerak dalam bidang pembangunan yang membutuhkan bahan-bahan bangunan. Tingginya harga bahan bangunan menyebabkan tingginya biaya produksi yang harus di tanggung oleh perusahaan. Kenaikan biaya produksi dapat membuat daya beli masyarakat akan menjadi menurun.

\section{Rumusan Masalah}

Dari latar belakang diatas penulis ingin melihat bagaimana pengaruh inflasi, kurs, harga minyak dan indeks harga bahan bangunan terhadap harga saham pada perusahaan sek tor properti di BEI periode 2008-2015 sebagai rumusan masalah.

\section{Tujuan Penelitian}

Dengan demikian tujuan penelitian ini adalah ingin mengetahui pengaruh inflasi, kurs, harga minyak dan indeks harga bahan bangunan terhadap harga saham, baik secara parsial maupun bersama-sama, yang akan dianalisa pada perusahaan sektor properti di BEI periode 2008-2015.

\section{KAJIAN PUSTAKA \\ Pasar Modal}

Pasar modal dapat diartikan sebagai suatu bidang usaha perdagangan suratsurat berharga seperti saham, sertifikat saham, dan obligasi. Dalam pengerian klasik, seperti dapat dilihat dalam praktek-prakteknya di negara-negara kapitalis, perdagangan efek sesungguhnya merupakan kegiatan perusahaan swasta. Motif utama terletak pada masalah kebutuhan modal bagi perusahaan yang ingin lebih memajukan usaha dengan menjual sahamnya pada para pemilik uang atau investor baik golongan maupun lembaga-lembaga usaha.

\section{Harga Saham}

Setiap investor yang melakukan investasi saham memiliki tujuan mendapatkan manfaat yang lebih besar dari apa yang dibayarkan pada saat membeli saham. Saham adalah sertifikat yang menunjukkan bukti kepemilikan suatu perusahaan dan pemegang saham memiliki hak klaim atas penghasilan dan aktiva perusahaan. Harga saham merupakan harga yang terjadi di pasar bursa pada saat tertentu yang ditentukan oleh permintaan dan penawaran saham yang bersangkutan (Jogiyanto, 2010). Harga sebuah saham sangat dipengaruhi oleh hukum permintaan dan penawaran, harga suatu saham akan cenderung naik bila suatu saham mengalami kelebihan permintaan dan cenderung turun jika terjadi kelebihan penawaran.

\section{Nilai Tukar (Kurs)}

Nilai tukar atau yang sering disebut juga kurs valuta dalam berbagai transaksi ataupun jual beli valuta asing. Bagi investor sendiri, depresiasi rupiah terhadap dollar menandakan perekonomian Indonesia dalam kondisi yang kurang baik. Depresiasi rupiah ini dapat terjadi apabila faktor fundamental perekonomian Indonesia tidaklah kuat (Sunariyah, 2010). Bila terjadi penurunan kurs yang berlebihan, akan berdampak 
pada perusahaan-perusahaan go public yang menggantungkan pemenuhan faktorfaktor produksinya terhadap barang-barang impor. Besarnya belanja impor dari perusahaan seperti ini bisa mempertinggi biaya produksi, serta menurunnya laba perusahaan. Selanjutnya dapat saja menyebabkan harga saham perusahaan itu akan turun.

\section{Inflasi}

Dalam ilmu ekonomi inflasi adalah suatu proses meningkatnya harga-harga secara umum dan terus menerus berkaitan dengan mekanisme pasar yang dapat disebabkan oleh berbagai faktor, antara lain, konsumsi masyarakat yang meningkat, berlebihnya likuiditas di pasar yang memicu konsumsi atau bahkan spekulasi, sampai termasuk juga akibat adanya ketidak lancaran distribusi barang (Suparmoko, 2008). Hal ini tentu saja akan mempengaruhi kenaikan biaya produksi pada suatu perusahaan. Biaya produksi yang tinggi tentu saja akan membuat harga jual barang naik, sehingga akan menurunkan jumlah penjualan yang akan berdampak buruk terhadap kinerja perusahaan yang tercermin dengan turunya return saham perusahaan tersebut. Kenaikan laju inflasi yang tidak diantisipasi akan meningkatkan harga barang dan jasa, sehingga konsumsi akan menurun. Selain itu kenaikan harga faktor produksi juga akan meningkatkan biaya modal perusahaan. Sehingga pengaruh dari kenaikan laju inflasi yang tidak diantisipasi tersebut akan menurunkan harga saham.

\section{Harga Minyak}

Witjaksono (2010) mengemukakan bahwa kenaikan harga minyak secara umum akan mendorong kenaikan harga saham sektor pertambangan. Hal ini disebabkan karena dengan peningkatan harga minyak akan memicu kenaikan harga barang. tambang secara umum. Minyak mentah atau yang juga dikenal sebagai Crude Oil merupakan komoditas dan kebutuhan utama dunia saat ini. Investor pasar modal menganggap bahwa naiknya harga-harga energi merupakan pertanda meningkatnya permintaan global, yang berarti membaiknya perekonomian global. Sebaliknya, harga energi yang turun mencerminkan melemahnya pemulihan ekonomi global. Dengan begitu, jika harga minyak mentah meningkat, ekspektasi terhadap membaiknya kinerja perusahaan-perusahaan juga akan meningkat dan otomatis harga sahamnya akan ikut terkerek naik.

\section{Harga Bahan Bangunan}

Bahan bangunan merupakan salah satu komponen penting dalam membuat bangunan permanen dalam perusahaan properti. Indonesia merupakan salah satu konsumen terbesar di ASEAN dalam penggunaan bahan bangunan selain Vietnam dan Thailand. Ketika bahan bangunan semen naik atau turun, mengakibatkan produksi pembangunan bisnis properti berdampak dengan harga saham perusahaan properti. Hal ini tentu akan membuat perubahaan harga saham yang diperjualbelikan di pasar modal. Data indeks bahan bangunan dapat dilihat pada data Badan Pusat Statistik. Indeks Perdagangan Besar disajikan dalam bentuk Indeks Umum dan berdasarkan pengelompokkan barang yang disajikan oleh BPS, dimana salah satunya adalah kelompok bahan-bahan bangunan/konstruksi. (Badan Pusat Statistik, 2017) 


\section{METODE PENELITIAN}

Penelitian ini dilakukan pada bulan Januari sampai dengan Juni 2017. Penelitian ini merupakan penelitian kuantitatif yang bertujuan untuk mengetahui pengaruh antara variabel bebas/independen yaitu, tingkat inflasi $\left(\mathrm{X}_{1}\right)$, nilai tukar $\left(\mathrm{X}_{2}\right)$, harga minyak $\left(\mathrm{X}_{3}\right)$, indeks harga bahan bangunan $\left(\mathrm{X}_{4}\right)$ terhadap variabel terikat/dependen, yaitu harga saham (Y). Dalam penelitian ini variabel dependent yaitu harga saham pada perusahaan properti (Y) data yang digunakan dalam penelitian ini adalah harga saham yang dilaporkan perbulan yang tercatat dari tahun 2008 sampai dengan 2015. Kemudian data dihitung dengan menggunakan rumus sebagai berikut :

$$
\mathrm{P}_{\mathrm{n}}=\frac{H_{n}-H_{n-1}}{H_{n-1}} \times 100 \%
$$

$\mathrm{P}_{\mathrm{n}} \quad=$ Harga saham awal / Harga saham pada periode $\mathrm{n}$

$\mathrm{P}_{\mathrm{n}-1} \quad=$ Harga saham akhir/ Harga saham pada periode $\mathrm{n}-1$

Dalam penelitian ini menggunakan empat variabel bebas. Data inflasi yang digunakan adalah yang tercatat tiap bulan selama tahun 2008 sampai dengan 2015 . Variabel nilai tukar atau kurs adalah harga mata uang dollar Amerika Serikat dalam mata uang domestik yaitu Rupiah. Variabel ini diukur dengan menggunakan kurs tengah Dollar US terhadap Rupiah yang dikeluarkan oleh Bank Indonesia setiap bulannya. Dalam penelitian ini penulis menggunakan data sekunder dan laporan dari Bank Indonesia (BI) dan yahoo finence. Harga minyak dunia dalam penelitian ini adalah harga minyak mentah dunia yang diukur dari harga spot pasar minyak dunia. Saat ini patokan harga minyak mentah yang umum digunakan adalah West Texas Intermediate (WTI) atau light-sweet. Minyak mentah yang diperdagangkan di West Texas Intermediate (WTI) adalah minyak mentah yang berkualitas tinggi (useconomy.about.com). Harga bahan bangunan yang digunakan adalah indeks harga bahan bangunan yang tercatat pada tahun 2008 sampai dengan 2015.

Populasi dalam penelitian ini adalah harga saham yang diperoleh dari situs yahoo finance. Metode pemilihan sampel yang digunakan adalah purposive sampling, dimana peneliti memiliki kriteria tertentu terhadap sampel yang akan diteliti. Kriteria yang digunakan dalam penelitian ini adalah sebagai berikut: a) Perusahaan yang telah dan masih tercatat (listed) di Bursa Efek Indonesia pada Januari tahun 2008 sampai Desember 2015; b) Mempunyai kelengkapan data yang dibutuhkan dalam penelitian dari tahun 2008 hingga 2015.

Dalam penelitian ini, data yang digunakan adalah data sekunder yang berupa harga saham perusahaan properti di BEI yang diperoleh dari media internet. Dan untuk harga saham tiap perusahaan didapat dari situs informasi keuangan terkemuka yaitu yahoo finance.

Model analisis yang dipakai dalam penelitian ini adalah menggunakan analisis regresi berganda dengan menggunakan perangkat lunak SPSS. Analisis yang dianalisa adalah melihat ada atau tidaknya pengaruh signifikansi variabel independen yaitu inflasi, nilai tukar rupiah, harga minyak dunia dan indeks harga bahan bangunan harga saham. Sebelum dilakukan regresi data-data terlebih dahulu harus melewati uji asumsi klasik, yaitu uji normalitas, multikolinieritas. 
Uji normalitas digunakan untuk mengetahui data yang digunakan berdistribusi secara normal. Untuk uji normalitas Salah satu metode adalah dengan menggunakan metode analisis grafik, yaitu grafik histogram ataupun dengan melihat grafik Normal Probability Plot. jika histogram standardized regression residual membentuk kurva seperti lonceng maka nilai residual tersebut dinyatakan normal. Uji multikolinieritas digunakan untuk mengatahui adanya korelasi yang tinggi antara variabel bebas. Uji multikolinieritas dilakukan dengan melihat Tolerance (TOL) dan Variance Inflation Factor (VIF) dari masing-masing variabel bebas terhadap variabel terikat. Jika nilai TOL kurang dari 0,1 dan nilai VIF lebih besar dari 10, maka dinyatakan terdapat multikolinieritas.

Uji Heterokedastisitas bertujuan menguji apakah dalam model regresi terjadi ketidaksamaan variance dari residual satu pengamatan ke pengematan yang lain. Jika variance dari residual satu pengamatan ke pengamatan tetap, maka disebut homoskedastisitas dan jika berbeda disebut heteroskesdatisitas. Model regresi yang baik adalah yang homoskesdatisitas atau tidak terjadi heteroskesdatisitas. Uji autokorelasi bertujuan menguji apakah dalam model regresi linear ada korelasi antara kesalahan pengganggu pada periode t-1 (sebelumnya). Jika terjadi korelasi, maka dinamakan ada problem autokorelasi. "Jika angka DW dibawah -2 berarti ada autokorelasi positif, jika angka DW diantara -2 sampai +2 berarti tidak ada autokorelasi, dan jika angka DW diatas +2 berarti ada autokorelasi negatif." (Ghozali,2006)

Uji regresi linier berganda dilakukan terhadap model regresi sebagai berikut:

$$
\mathbf{Y}=\mathbf{a}+\boldsymbol{\beta}_{1} \mathbf{X}_{1}+\boldsymbol{\beta}_{2} \mathbf{X}_{2}+\boldsymbol{\beta}_{3} \mathbf{X}_{3}+\boldsymbol{\beta}_{\mathbf{4}} \mathbf{X}_{\mathbf{4}}+\mathbf{e}
$$

Dimana: $\mathrm{Y}$ adalah perubahan harga saham, $\mathrm{X}_{1}$ adalah inflasi, $\mathrm{X}_{2}$ adalah kurs, $\mathrm{X}_{3}$ adalah harga minyak dunia, $\mathrm{X}_{4}$ adalah indeks harga bahan bangunan, dan e adalah error.

Uji hipotesis yang dilakukan adalah uji parsial (uji t) dan uji simultan. Uji t digunakan untuk mengetahui pengaruh variabel bebas terhadap variabel terikat secara parsial. Apabila signifikan hitung lebih besar dari signifikan yang ditentukan (sig>0,10), maka variabel bebas tidak berpengaruh terhadap variabel terikat. Sebaliknya apabila signifikan hitung kurang dari signifikan yang ditentukan $(\operatorname{sig}<0,10)$, maka variabel bebas berpengaruh terhadap variabel terikat. Uji simultan (Uji F) digunakan untuk mengetahui pengaruh variabel bebas secara simultan terhadap variabel terikat. Jika signifikan hitung lebih besar dari signifikan yang ditentukan (sig >0,05), maka variabel bebas secara simultan tidak berpengaruh terhadap variabel terikat. Jika signifikan hitung kurang dari signifikan yang ditentukan $(\operatorname{sig}<0,05)$, maka variabel bebas secara simultan berpengaruh terhadap variabel terikat.

Selain itu juga dilihat koefisien determinasi untuk mengukur seberapa besar kemampuan variabel bebas dalam mempengaruhi variabel terikatnya. Menurut Ghozali (2006) 'Nilai Adjusted $R$ Square yang lebih kecil berarti kemampuan variabel independen dalam menjelaskan variasi variabel dependen sangat terbatas." 


\section{HASIL PENELITIAN DAN PEMBAHASAN}

Dari saham-saham 36 perusahaan properti di Bursa Efek Indonesia, dipilih 5 perusahaan yang memiliki kelengkapan data-data keuangan selama periode 2008 sampai dengan 2015. Lima perusahaan tersebut adalah: Ciputra Development Tbk (CTRA), Alam Sutra Reality Tbk (ASRI), Modernland Realty (MDLN), Tbk Pakuwon Jati TbkV (PWON) dan Summarecon Agung Tbk (SMRA).

\section{Statistik Deskriptif}

Statistik deskriptif menunjukkan secara umun mengenai hasil dari analisis data dari sejumlah variabel yang digunakan pada model regresi. Pengukuran statistik deskriptif tersebut akan menggambarkan mean, standart deviasi, nilai maksimum dan nilai minimum dari variabel-variabel penelitian. Berikut hasil statistik deskriptif yang telah diolah menggunakan SPSS sebagai berikut.

\section{Tabel 1. Statis tik Deskriptif}

\begin{tabular}{|l|l|l|l|l|}
\hline & Minimum & Maximum & Mean & Std. Deviation \\
\hline perubahan_harga_saham & $-100,00$ & 66,67 & 2,5693 & 16,38439 \\
\hline Inflasi & 2,41 & 12,14 & 6,2205 & 2,32577 \\
\hline Kurs & 7 & 110 & 76,50 & 15,625 \\
\hline harga_minyak & 39,26 & 5983,00 & 687,5856 & 1602,39171 \\
\hline harga_semen & 1,04 & 22,22 & 13,6152 & 3,97671 \\
\hline
\end{tabular}

Sumber : Hasil Penelitian Diolah (www.idx.co.id)

\section{Uji Asumsi Klasik}

\section{Uji Normalitas}

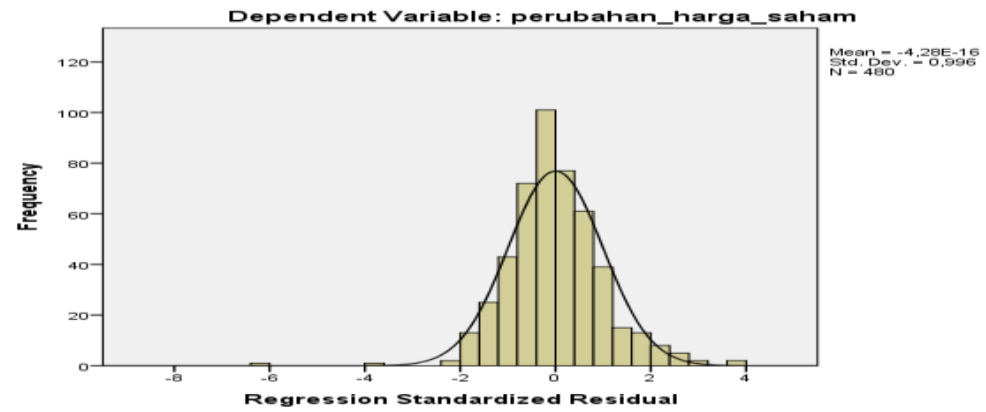

Gambar 1. Grafik Histogram

Sumber : Hasil Penelitian Diolah (2017)

Dari gambar diatas dapat diartikan bahwa kurva berbentuk seperti lonceng yang berarti dapat dikatakan bahwa data berdistribusi normal. Seperti halnya yang dikatakan oleh Suliyanto (2011:69) "Jika histogram standardized regression residual membentuk kurva seperti lonceng maka nilai residual tersebut dinyatakan normal." 


\section{Uji Multikolinieritas}

Tabel 2. Uji Multikolonie ritas

\begin{tabular}{|c|c|c|c|c|c|c|c|}
\hline \multirow[b]{2}{*}{ Model } & \multicolumn{2}{|c|}{$\begin{array}{l}\text { Unstandardized } \\
\text { Coefficients }\end{array}$} & \multirow{2}{*}{\begin{tabular}{|l} 
Standardizec \\
Coefficients \\
Beta
\end{tabular}} & \multirow[b]{2}{*}{$\mathrm{T}$} & \multirow[b]{2}{*}{ Sig. } & \multicolumn{2}{|c|}{$\begin{array}{l}\text { Collinearity } \\
\text { Statistics }\end{array}$} \\
\hline & $\overline{\mathrm{B}}$ & Std. Error & & & & Tolerance & VIF \\
\hline 1(Constant) &,- 596 & 7,226 & &,- 082 & ,934 & & \\
\hline Inflasi &,- 884 & 339 &,- 125 & $-2,605$ &, 009 &, 873 & 1,146 \\
\hline Kurs &, 126 &, 064 &, 120 & 1,962 &, 050 & ,538 & 1,857 \\
\hline harga_minyak &,- 002 &, 001 &,,- 177 & $-2,831$ &, 005 &, 517 & 1,935 \\
\hline harga_semen &, 019 &, 285 &, 005 &, 066 &, 947 & , 422 & 2,367 \\
\hline
\end{tabular}

a. Dependent Variable: perubahan_harga_saham

Sumber : Hasil Penelitian Diolah (2017)

Berdasarkan tabel diatas, variabel tingkat inflasi, nilai tukar, harga minyak dan harga semen tidak memiliki nilai TOL kurang dari 0,1 dan tidak memiliki nilai VIF lebih besar dari 10, maka dapat disimpulkan bahwa dalam penelitian ini tidak terjadi multikolinieritas.

\section{Uji Heteroskedastisitas}

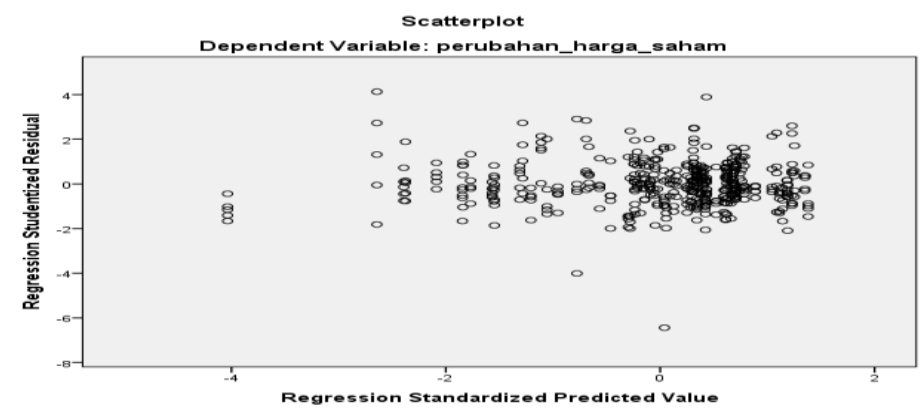

Gambar 2. Uji heteroskedastisitas

Sumber : Hasil Penelitian Diolah (2017)

Dari gambar diatas dapat disimpulkan bahwa hasil uji heteroskedastistas dengan grafik scatter plot terlihat bahwa titik-titik menyebar diatas dan dibawah angka 0 pada sumbu Y, berarti tidak terjadi heteroskedatistas.

\section{Uji Autokorelasi}

\section{Tabel 3. Autokorelasi}

\begin{tabular}{|l|l|l|l|l|l|}
\hline Model & $\mathrm{R}$ & $\mathrm{R}$ Square & $\begin{array}{l}\text { Adjusted } \\
\text { Square }\end{array}$ & $\begin{array}{l}\mathrm{R} \\
\text { Std. Error of } \\
\text { the Estimate }\end{array}$ & $\begin{array}{l}\text { Durbin- } \\
\text { Watson }\end{array}$ \\
\hline 1 &, $195^{\mathrm{a}}$ &, 038 &, 030 & 16,13832 & 1,944 \\
\hline
\end{tabular}

a. Predictors: (Constant), harga_semen, inflasi, kurs, harga_minyak

b. Dependent Variable:perubahan_harga_saham

Sumber : Hasil Penelitian Diolah (2017)

Berdasarkan hasil pengujian autokorelasi diperoleh nilai DW sebesar 1,944 yang terletak diantara di antara angka -2 sampai +2 , sehingga dapat disimpulkan bahwa dalam penelitian ini tidak ada korelasi antara kesalahan pengganggu pada periode $t$ dengan kesalahan pada periode $\mathrm{t}-1$ (sebelumnya). 
Uji Hipotesis

Uji Regresi Linier Berganda

Tabel 4. Uji Regresi Linier Berganda

\begin{tabular}{|l|l|l|l|l|l|}
\hline \multirow{2}{*}{ Model } & \multicolumn{2}{|l|}{$\begin{array}{l}\text { Unstandardized } \\
\text { Coefficients }\end{array}$} & $\begin{array}{l}\text { Standardized } \\
\text { Coefficients }\end{array}$ & & \\
\cline { 2 - 4 } & $\mathrm{B}$ & Std. Error & Beta & $\mathrm{t}$ & Sig. \\
\hline (Constant) &,- 596 & 7,226 & &,- 082 &, 934 \\
Inflasi &,- 884 &, 339 &,- 125 & $-2,605$ &, 009 \\
Kurs &, 126 &, 064 &, 120 & 1,962 &, 050 \\
harga_minyak &,- 002 &, 001 &,- 177 & $-2,831$ &, 005 \\
harga_semen &, 019 &, 285 &, 005 &, 066 &, 947 \\
\hline
\end{tabular}

a. Dependent Variable: perubahan_harga_saham

Sumber : Hasil Penelitian Diolah (2017)

Hasil pengujian analisis linear berganda dapat dijelaskan sebagai berikut:

PERUBAHAN HARGA SAHAM $=0,596-0,884$ INFLASI + 0,126 KURS

$-0,002$ HARGA MINYAK + 0,019 HARGA BANGUNAN

Hal ini berarti:

1. Konstanta sebesar 0,596, mempunyai arti apabila semua variabel independen sama dengan nol, maka perubahan harga saham sebesar 0,596.

2. Inflasimempunyai koefisien regresi sebesar -0,884, mempunyai arti setiap kenaikan inflasi sebesar 1 satuan atau 1\% maka perubahan harga saham turun sebesar 0,884 dengan asumsi faktor-faktor yang lain tetap atau ceteris paribus.

3. Kurs mempunyai koefisien regresi sebesar 0,126, mempunyai arti bahwa setiap kenaikan kurs sebesar $1 \%$ maka perubahan harga saham naik sebesar 0,126 dengan asumsi faktor-faktor yang lain tetap (ceteris paribus).

4. Harga minyak mempunyai koefisien regresi sebesar-0,002, mempunyai arti bahwa setiap kenaikan harga minyak sebesar $1 \%$ maka perubahan harga saham turun sebesar 0,002dengan asumsi faktor-faktor yang lain tetap (ceteris paribus).

5. Harga semen mempunyai koefisien regresi sebesar0,019, mempunyai arti bahwa setiap kenaikan harga semen sebesar $1 \%$ maka perubahan harga saham naik sebesar0,019 dengan asumsi faktor-faktor yang lain tetap (ceteris paribus).

\section{Uji Parsial (Uji t)}

Tabel 5. Uji Parsial

\begin{tabular}{|l|l|l|l|l|l|}
\hline \multirow{2}{*}{ Model } & \multicolumn{2}{|l|}{$\begin{array}{l}\text { Unstandardized } \\
\text { Coefficients }\end{array}$} & $\begin{array}{l}\text { Standardized } \\
\text { Coefficients }\end{array}$ & & \\
\cline { 2 - 4 } & $\mathrm{B}$ & Std. Error & Beta & $\mathrm{t}$ & Sig. \\
\hline (Constant) &,- 596 & 7,226 & &,- 082 &, 934 \\
Inflasi &,- 884 &, 339 &,- 125 & $-2,605$ &, 009 \\
Kurs &, 126 &, 064 &, 120 & 1,962 &, 050 \\
harga_minyak &,- 002 &, 001 &,- 177 & $-2,831$ &, 005 \\
harga_semen &, 019 &, 285 &, 005 &, 066 &, 947 \\
\hline
\end{tabular}

a. Dependent Variable: perubahan_harga_saham

Sumber : Hasil Penelitian Diolah (2017) 
Hasil pengujian hipotesis secara parsial dapat dijelaskan sebagai berikut:

Terdapat 3 variabel yang signifikan pengaruh terhadap harga saham yaitu variabel inflasi dengan nilai sebesar 0,009 lebih kecil dari 0,10 $(0,009<0,10)$, kurs dengan nilai sebesar 0,050 yang berarti lebih kecil dari $0,10(0,013<0,10)$ dan harga minyak dengan nilai sebesar 0,005 yang bearti lebih kecil dari $0,10(0,005<0,10)$. Seperti dasar pengambil keputusan Jika tingkat signifikan lebih kecil dari 10\% $(0,10)$ maka dapat disimpulkan bahwa variabel independen terdapat pengaruh terhadap variabel dependen. Sementara itu, terdapat 1 variabel yang tidak memiliki pengaruh terhadap harga saham yaitu harga semen memiliki nilai sebesar 0,947 yang lebih besar dari 0,10 $(0,947>0,10)$. Dari dasar pengambil keputusan, jika tingkat signifikan lebih besar dari $10 \%(0,10)$ maka dapat disimpulkan bahwa tidak memiliki pengaruh.

\section{Uji Simultan (uji F)}

Tabel 6. Uji Simultan

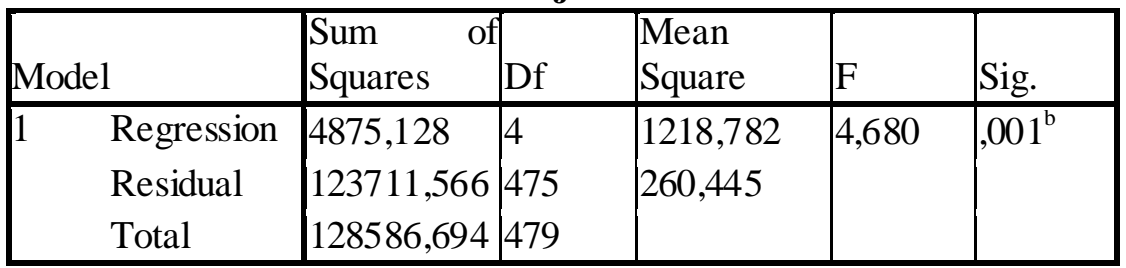

a. Dependent Variable: perubahan_harga_saham

b. Predictors: (Constant), harga_semen, inflasi, kurs, harga_minyak

Sumber : Hasil Penelitian Diolah (2017)

Dari hasil tabel 6, menggambarkan bahwa dari hasil perhitungan diatas dapat dilihat bahwa nilai signifikansi yang didapat sebesar 0.001 dan nilai $\mathrm{F}$ hitung sebesar 4,680. Dari pengambilan keputusan adalah tingkat signifikansinya sebesar 0,05. Karena nilai signifikansinya lebih kecil dari 0,05 maka berarti menunjukan bahwa adanya pengaruh tingkat inflasi, kurs, harga minyak dan harga semen terhadap harga saham.

\section{Koefisien Determinasi}

Tabel 7. Koefisien determinasi

\begin{tabular}{|l|l|l|l|l|l|}
\hline Model & R & R Square & Adjusted R Square & $\begin{array}{l}\text { Std. Error of the } \\
\text { Estimate }\end{array}$ & Durbin-Watson \\
\hline 1 &, $195^{\text {a }}$ &, 038 &, 030 & 16,13832 & 1,944 \\
\hline
\end{tabular}

a. Predictors: (Constant), harga_semen, inflasi, kurs, harga_minyak

b. Dependent Variable: perubahan_harga_saham

Sumber : Hasil Penelitian Diolah (2017)

Hasil dari tabel 7 diperoleh nilai koefisien determinasi (Adjusted R) sebesar 0,030. Dari hasil tersebut dapat disimpulkan bahawa perubahan harga saham dapat dijelaskan oleh tingkat inflasi, kurs, harga minyak dan harga semen dapat menjeleaskan perubahan harga saham sebesar 3\% sedangkan sisanya yaitu 97\% (100\%-3\%) dipengaruhi oleh faktor lain yang tidak diteliti atau dijelaskan dalam penelitian ini. 


\section{KESIMPULAN DAN SARAN \\ Kesimpulan}

Inflasi, nilai tukar dan harga minyak berpengaruh terhadap perubahan harga saham, inflasi yang naik turun akan mempengaruhi harga saham. Penurunan tingkat inflasi akan memberikan sinyal positif bagi investor. Nilai tukar juga memiliki pengaruh, kuat atau melemahnya kurs rupiah terhadap Dollar US berpengaruh pada perubahan harga saham perusahaan. Saat kurs berfluktuasi, maka nilai dollar atas barang impor yang dibeli juga berfluktuasi. Jika kurs jatuh atau rupiah terdepresiasi akan berdampak negatif untuk perusahaan yang bahan bakunya impor dari luar. Saat kurs jatuh maka harga saham juga akan turun dan akan menyebabkan perusahaan tidak menarik untuk investor. Sedangkan harga minyak sering menjadi sorotan investor karena akan berdampak pada harga-harga lainya. Peristiwa tersebut dapat diikuti dengan perubahan laju Inflasi.

Indeks harga bangunan tidak berpengaruh terhadap perubahan harga saham pada perusahaan sektor properti, karena bahan baku ini menjadi ruang lingkup suplier atau pihak ketiga. Hasil penelitian menunjukkan investor belum melihat harga bahan bangunan untuk menjadi acuan dalam menanamkan investasi atau dananya pada perusahaan properti .

Dalam melihat perubahan harga saham perusahaan sektor properti perlu diperhatikan faktor-faktor ekonomi makro. Namun, koefisien determinasi yang kecil menunjukkan bahwa variabel-variabel makro ternyata bukan merupakan variabel terutama yang digunakan oleh investor dalam menentukan pembelian saham properti. Banyak faktor lain yang dilihat oleh investor, seperti kemajuan perusahaan, kesehatan keuangan perusahaan, kinerja perusahaan, sistem organisasi dalam perusahaan tersebut, fasilitas yang dimiliki, keberlangsungan kontrak yang baik dengan para supplier atau pihak ketiga, penguasaan terhadap teknologi dan informasi dalam era globalisasi ini, serta faktor-faktor lainnya.

\section{Saran}

Dalam penelitian selanjutnya disarankan untuk memasukkan juga variabelvariabel ekonomi mikro sehingga dapat memperbesar koefisien determinasi dari model.

\section{DAFTAR PUSTAKA}

Badan Pusat Statistik. 2017. Indeks Harga Perdagangan Besar Bahan Bangunan / Konstruksi Indonesia, 2002-2017. https://www.bps.go.id/statictable /2009/07/02/1458/indeks-harga-perdagangan-besar-bahan-bangunan-konstruksimenurut-jenis-bangunan-konstruksi-bulanan-2002-2017.html

Ghozali, Imam. 2016. Aplikasi Analisis Multivariate dengan Program SPSS. Semarang: Badan Penerbit Universitas Diponegoro.

Jogiyanto, H.M. 2010 . Teori Portofolio dan Analisis Investasi. Edisi Ketujuh. Yogyakarta. : BPFE

Samsul, Mohamad. 2016. Pasar Modal dan Manajemen Portofolio Surabaya: Penerbit Erlangga. 
Sunariyah. 2010. Pengantar Pengetahuan Pasar Modal, Edisi ke-6. Yogyakarta: UPP STIM YKPN

Suparmoko, M. 2008. Keuangan Negara Dalam Teori dan Praktek, Edisi Kelima. Yogyakarta. : BPFE

Tandelilin, Eduardus. 2010. Portofolio dan Investasi. Yogyakarta: Kanisius.

Witjaksono, A. A. 2010. Analisis Pengaruh Tingkat Suku Bunga SBI, Harga Minyak

Dunia, Harga Emas Dunia, Kurs Rupiah, Indeks Nikkei 225, dan Indeks Dow

Jones terhadap IHSG (studi kasus pada IHSG di BEI selama periode 2000-2009).

Masters thesis, Universitas Diponegoro.

www.idx.co.id

www.useconomy.about.com

www.yahoofinance 